\title{
DID Analysis on the Impact of Policies on the Rural-Urban Income Disparity in Resource-Dependent Regions: A Case Study of Ordos
}

\author{
Rijimoleng $\mathrm{Si}^{1} \&$ Gang $\mathrm{Han}^{2,3}$ \\ ${ }^{1}$ Department of Economics, Central University of Finance and Economics, Beijing, China \\ ${ }^{2}$ The School of Finance, Renmin University of China, Beijing, China \\ ${ }^{3}$ Manager, Beijing Xinhua Fantai Financial Services Outsourcing Co. LTD, Beijing, China \\ Correspondence: Rijimoleng Si, Department of Economics, Central University of Finance and Economics, \\ Beijing 100081, China. Tel: 86-130-1180-6337. E-mail: sirijimoleng_cufe@ hotmail.com
}

Received: June 5, 2018

doi:10.5539/ijef.v10n7p191
Accepted: June 28, 2018

Online Published: June 30, 2018

\begin{abstract}
Ordos is the most abundant coal resource city in Inner Mongolia. Its coal resources account for one half of Inner Mongolia's coal resources and one sixth of China's total coal reserves. Abundant coal resources have laid the foundation for Ordos become today's resource-based city. In 2003, Inner Mongolia issued "the guiding opinions on accelerating the development of key coal enterprises" (hereinafter referred to as "policy"), supporting the development of coal enterprises and providing policy conditions for the rapid economic development of Ordos. However, with the rapid development of economy, the rural-urban income disparity is also getting bigger in Ordos. Based on panel data from 1999 to 2012 and use the DID analysis of "quasi-natural experiment", the paper finds that the policy has increased the rural-urban income disparity. The policy increases the rural-urban income disparity by promoting GDP growth. Therefore, the role of the policy system in the economic development of a region cannot be ignored. The government supports the development of local resource-based industries and also increase support for the development of upstream and downstream industries. Under the guidance of policy, the mineral resources income should be transformed reasonably. Government should invest the proceeds of mineral resources in material capital and human capital. Government also should invest the proceeds of mineral resources in external industries and projects that require large initial capital or long construction cycles, such as those essential infrastructure sectors: education, health, transportation and energy. In this way, the integration of urban and rural development will be realized and the rural-urban income disparity will be reduced.
\end{abstract}

Keywords: policy, rural-urban income disparity, resource-dependent regions, economic development, DID analysis, Ordos

\section{Introduction}

Due to geographical location and natural climate and other reasons, China's western regions have been lagging behind in economic development for a long time. However, its abundant resource endowment has laid a solid foundation for the birth of today's resource-based cities, of which Ordos is a typical one. Ordos is particularly rich in coal resources, accounting for about half of the coal resources in Inner Mongolia and 1/6 of the total national reserves. Ordos actively caters to the national western development policy, and with the help of the national energy policy opportunity, achieved leapfrog economic development. In 2003, the local government issued relevant policies to support the development of coal enterprises. Taking advantage of resources, the regional GDP in 2016 has reached 30 times that of 2000. Ordos relies heavily on natural resources, especially coal resource. As can be seen from Figure 1, the economic growth of ordos is highly correlated with the production of coal resources, especially after 2003, the production of coal resources and the economic growth trend chart increased sharply. It can be seen that the policy of 2003 played a role in the economic development of Ordos. In 2003, in order to encourage the rapid development of energy enterprises, the Ordos government issued the guiding opinions on accelerating the development of key coal enterprises (hereinafter referred to as "policy") (Note 1). It is pointed out that the key state-owned coal mining enterprises take advantage of the historic opportunity of the policy that revitalize the old industrial base in northeast China, to strive for national policy support, enjoy relevant preferential policies to realize the own economic development. 
The policy gives priority support to 20 enterprises as region leading enterprises in the coal industry. The contribution of coal resources to economic growth has risen sharply since 2003. The first year after the opinions were issued (2004) coal energy consumption per unit of GDP in ordos reached an all-time high. In the second year (2005), the GDP of ordos region reached the highest point in history. Ordos has enjoyed the first GDP growth rate in Inner Mongolia for 15 consecutive years and the first GDP growth rate in China for 9 consecutive years. Its per capita GDP has surpassed Beijing, Shanghai and Hong Kong and become the richest city in China (Note 2).



Figure 1. 2001-2015 economic and coal production trend of ordos

According to the research of Lin yifu, the development of comparative advantage can improve the structure of factor endowment, change the relative price of capital and labor, not only promote economic growth, but also improve the income distribution (Note 3). Did Ordos's income distribution improve as its economy grew rapidly? What changes have been made in the rural-urban income disparity with the development of the economy after the policy of the ordos government in 2003? In order to answer the above questions, the introduction of the policy in 2003 was taken as the starting point of the policy. The investigation period was 2000-2015. The DID method of "quasi-natural experiment" was used to evaluate the effect of economic development strategy on the rural-urban income disparity.

The structure of the paper is as follows: the second part analyzes the existing research literature and puts forward the research contribution of this paper. The third part, DID model construction and variable description. The fourth part is empirical analysis. The empirical test was conducted on the changes of the rural-urban income disparity between the two cities around 2003 by using data samples from 1999-2012 in ordos city and bayannur city (cities where coal is mined and coal is not mined). In the fifth part, we do the robust test. The robust test was conducted on the changes of the rural-urban income disparity between the two cities around 2003 by using data samples from 1978-2012 in ordos city and bayannur city. The sixth part is the conclusion and policy implications.

\section{Literature Review}

Since the reform and opening-up, ordos economy has developed rapidly with the national revitalization of the northeast old industrial area and the western development policies. According to the ordos statistics bureau, the GDP of ordos increased from 15.09 billion yuan in 2000 to 441.79 billion yuan in 2016, an increase of about 30 times. The per capita GDP of ordos has already exceeded the national average, reaching 214,952 yuan in 2016, compared with 53,980 yuan nationwide. In the 15 years from 2000 to 2015, the change of gross domestic product in ordos region was similar to the change of coal energy consumption per unit of GDP, both of which showed a trend of increasing first and then decreasing (see Figure 2). In 2001, the GDP of ordos increased by $14.5 \%$ at comparable prices and $36 \%$ in 2003 . It grew the most in 2005 , by $74 \%$. During this period, ordos coal energy consumption per unit of GDP also appeared the same change trend, increased from 17.85 in in 2000 to 
highest level of 32.27 in in 2004. The reason of this amassing increase of coal energy consumption per unit of GDP in 2004 is probably due to the policies of the Inner Mongolia government in 2003. From 2006 to 2015, except for individual years, the growth rate decreased year by year, increasing by $4.2 \%$ in 2015 . Over the same period, coal consumption per unit of GDP increased in 2010 and 2011, but declined in the rest of the year, falling to $14.57 \mathrm{w}$ in 2015. From the above changes, it can be seen that the economic growth of ordos is highly correlated with coal consumption. The economic growth mainly depends on the input of production factors and excessive dependence on natural resources. In order to change the extensive economic development mode, the ordos government has been actively constructing projects such as "coal to electricity" and "coal to oil". Ordos Relying on science and technology to establish the upstream and downstream industrial chain of the coal industry, enhance the added value of products, strive to accumulate capital, technology, personnel and other elements. Ordos has achieved a gradual reduction in coal consumption per unit of GDP, but still lags far behind the national level. Ordos government actively transformed the industrial structure, relying on coal resources, won the first bucket of gold and changing the situation of 5 national-level poverty-stricken banner counties and 3 autonomous region poverty-stricken banner counties in the 7 banner 1 district of the city before the 1990s. Ordos actively invests and develops the real estate industry since get the first bucket gold (Note 4). After 2009, the real estate industry was depressed due to the impact of the international financial crisis. However, the coal industry plays a major role in promoting economic development. That's why coal consumption per unit of ordos' GDP continued to rise two years after 2009, to 18.27\% in 2011.



Figure 2. 2001-2015 economic growth rate and coal energy consumption per unit of GDP in ordos

Ordos has realized rapid economic development by relying on its abundant coal resource endowment. Ordos's per capita GDP is much higher than the national average, about four times the national average in 2016. What changes have taken place in the rural-urban income disparity in ordos at an alarming rate of economic development?

The relationship between economic growth and the rural-urban income disparity has already attracted high attention from domestic and foreign scholars and in-depth discussion from multiple perspectives. However, the conclusions are different because of different perspectives, samples, theoretical basis, model building and empirical methods. Aghion et al. (1999) found that, when credit markets are imperfect, investment opportunities depend on individuals' assets and income levels. Low-income people are more likely to invest in human capital with a higher return, so the income gap is good for economic growth. Wang tongsan and Cai yuezhou (2006) analyzed the relationship between the the rural-urban income disparity on investment and economic growth in China. It is believed that the increase of the rural-urban income disparity leads to the increase of the proportion of heavy industry in the investment structure and the increase of the economic growth rate, that is, there is a positive correlation between rural-urban income disparity and economic growth. Alesina and Perotti (1996), castello and Domenech (2003), Knowles (2005) et al. also found that there was a negative correlation between income gap and economic growth. That is, the narrowing of income gap was conducive to economic growth. 
Kuznets (1955) believed that there was an "inverted u-shaped" relationship between economic growth and income inequality. When the overall income distribution consists of the income distribution of the rural population and the income distribution of the urban population, there are significant differences between urban and rural sectors in income level and income inequality, which leads to the increase of overall income inequality in the course of economic development. Only after the economy reaches the middle-income level will the income inequality between the departments and within the sector continue to decline with economic growth. Kuznets' conclusion is consistent with the conclusion of Lewis's (1954) two-department model. Sherman Robinson (1976) proved the rationality of Kuznets curve by mathematical method. With the implement of western development policy and local government actively to support national policy put forward the rapid development of the coal enterprise policy. The economy of ordos has achieved amazing development. The per capita GDP has far exceeded the national average level, making ordos the fastest city in China's economic development. From the perspective of GNP, ordos has reached the level of middle income. Has the rural-urban income disparity been improved during the economic development of ordos? Lin yifu and Chen binkai (2013) found through empirical test that the development strategy of heavy industry in backward countries has resulted in low urbanization level and high rural-urban income disparity. Lin yifu (2012) pointed out in his book interpreting China's economy that, since the founding of new China, the Chinese government has implemented a development strategy with no comparative advantages that gives priority to the development of heavy industry. Although the initial development goals have been achieved to a large extent, they have brought serious costs and it is difficult to improve people's living standards. Japan and the "Asian tigers" developed rapidly after the second world war to catch up with developed countries because they developed their comparative advantage enterprises through the strategy of comparative advantage. Kanbur and zhang (2005) believed that the strategy of prioritizing the development of heavy industry and the resulting government intervention policy were the important reasons for the widening rural-urban income disparity in China. Xia hua (2011) believes that the fundamental reason for the widening income gap is "low industrialization". The low industrialization growth mechanism refers to the promotion of industrialization with the "low price" of production factors under the government's intervention, resulting in low labor income. Through sorting out the existing literature, it is found that there are mainly three theories about the relationship between economic growth and the rural-urban income disparity. First, the rural-urban income disparity is conducive to economic development. Second, the rural-urban income disparity is not conducive to economic development. Third, as the economy develops, there is an "inverted u-shaped relationship" between rural-urban income disparity and economic growth. In this paper, we think as the economy growth, the rural-urban income disparity may widen or decrease. The result depends on whether the economic development strategy has comparative advantage. Such as Lin pointed out, has no comparative advantage development strategy, although the economy is likely to achieve the goal of development, but the cost behind it is a series of problems, such as inequality of income distribution and social contradictions. If the development strategy has comparative advantages, like the rapid development of the Asian tigers after the second world war, can realize the rapid economic development while realizing the rationalization of income distribution.

In order to answer the questions raised in the introduction, based on 1999-2012 data samples of ordos and bayannur city, use DID (different in different) method, analyze the changes of the rural-urban income disparity between the two cities around 2003 with the economy growth. To test the robustness of the empirical model, in this paper, the data samples of ordos city and bayannur city from 1978 to 2012 were used to further analyze the rural-urban income disparity in two adjacent cities around 2003. At last, on the basis of empirical analysis, relevant policy implications are proposed.

\section{DID Model Construction and Variable Description}

Ordos is particularly rich in coal resources, accounting for about half of the coal resources in Inner Mongolia and $1 / 6$ of the total national reserves. Ordos actively caters to the national western development policy, and by virtue of the policies of Inner Mongolia government in 2003 to support the development of energy enterprises, exploiting the advantages of resources, achieve the leapfrog development of economy. Bayannur, a neighboring city in ordos, has little coal. Yet it is clearly not affected by the government policy in 2003. Based on the actual situation, using the method of "natural experiment" DID model, analysis the influence of 2003 policy on the rural-urban income disparity. ${ }^{[13]}$ The basic idea is to divide the research samples into two groups: one is ordos city (treatment group), which is affected by the policy of mining coal resources, the dummy variable is treated $=1$. The other group was treated $=0$ by bayannur city (control group), which was not affected by the policy and did not exploit coal resources. At the same time, set the time dummy variable t. The year after the policy is introduced $\mathrm{t}=1$, and the other years $\mathrm{t}=0$. 
According to the above definition, in order to test the change of the rural-urban income disparity before and after the policy in 2003, the regression model based on DID method is set as follows:

$$
\text { inc_ratio }_{i t}=\delta_{0}+\delta_{1} \text { treated }_{i t}+\delta_{2} t_{i t}+\delta_{3} \text { treated }_{i t} \times t_{i t}+\beta X_{i t}+C_{t}+C_{i}+\varepsilon_{i t}
$$

Where, inc_ratioit refers to the rural-urban income disparity of region i in the period t. By referring to existing literature, such as Lin yifu and Chen binkai, in this paper, the rural-urban income disparity is represented by the ratio of annual disposable income per person in urban households to annual net income per person in rural households. The higher the ratio, the greater the gap between urban and rural incomes. $\mathrm{X}$ is a set of observable control variables that influence the rural-urban income disparity over time. According to the general practice of previous scholars such as wang xiaolu and fan gang (2005) and data availability, X includes investment rate (RI), urbanization rate (URB), social welfare undertakings (PW), per capita education years (ED), government intervention degree (GI). $\mathrm{C}_{\mathrm{t}}$ is the annual fixation effect. $\mathrm{C}_{\mathrm{i}}$ is a non-observable effect that controls unobservable factors that do not change over time. $\varepsilon_{i t}$ is the random error term. The relevant variable definitions are detailed in table 1.

As can be seen from equation (1), for the control area (treated=0), the change of the rural-urban income disparity before and after the policy is $\delta_{0}$ and $\delta_{0}+\delta_{2}$ respectively. Therefor the difference between rural-urban income disparity before and after the implementation of the policy is diff $f_{0}=\delta_{2}$ in the areas not affected by the policy. This difference can be seen as the difference in time trend between the rural-urban income disparity that ruling out the impact of government policies. For treatment group areas (treated=1), the rural-urban income disparity before and after the policy is $\delta_{0}+\delta_{1}$ and $\delta_{0}+\delta_{1}+\delta_{2}+\delta_{3}$. The difference is diff $f_{1}=\delta_{2}+\delta_{3}$. This difference includes not only the impact of the policy $\delta_{3}$, but also the time trend differences $\delta_{2}$. Therefore, the net effect of the policy on the rural-urban income disparity is diff $=\operatorname{diff} f_{1}-\operatorname{diff} f_{0}=\delta_{2}+\delta_{3}-\delta_{2}=\delta_{3}$. From the original equation, $\delta_{3}$ is the DID estimator, the main coefficient as we concerned. If the policy increases the rural-urban income disparity, the coefficient should be significantly positive. In this paper, the unobserved effect $\mathrm{C}_{\mathrm{i}}$ is eliminated through intra-group difference using panel data. So we get a consistent estimate. Therefore, the panel double checking model is adopted to estimate equation (1).

To further test the extent to which policies affect the rural-urban income disparity by promoting economic growth, we introduce the economic growth variable per capita GDP and its interaction terms with the treatment of dummy variables and $t$. The regression model is as follows:

$$
\begin{gathered}
\text { inc_ratio }_{i t}=\gamma_{0}+\gamma_{1} G D P_{i t}+\gamma_{2} t_{i t}+\gamma_{3} \text { treated }_{i t}+\gamma_{4} t_{i t} \times G D P+\gamma_{5} \text { treated }_{i t} \times G D P+\gamma_{6} \text { treated }_{i t} \times \\
t_{i t}+\gamma_{7} \text { treated }_{i t} \times t_{i t} \times G D P+\lambda Z_{i t}+v_{t}+v_{i}+\xi_{i t}
\end{gathered}
$$

Where, the GDP ${ }_{i t}$ is the per capita GDP in period t of region $i$, and the coefficient is expected to be positive if the government's policy of supporting coal enterprises increases the rural-urban income disparity through economic growth. $\mathrm{Z}$ is another control variable that affects the rural-urban income disparity besides per capita GDP. According to the general practice of previous scholars such as wang xiaolu and fan gang (2005) and data availability, $\mathrm{Z}$ includes investment rate (RI), urbanization rate (URB), social welfare undertakings (PW), per capita education years (ED), government intervention degree (GI). The $v_{t}$ is the annual fixation effect. $v_{i}$ is a non-observable effect that controls unobservable factors that do not change over time. The $\xi_{i t}$ is the random error term. The relevant variable definitions are detailed in table 1 .

As can be seen from equation (2), for the control area (treated=0), the effect of regional GDP per capita on the rural-urban income disparity (inc_ratio) before and after the introduction of the policy is $\gamma_{1}$ and $\gamma_{1}+\gamma_{4}$ respectively. It can be seen that the effect of per capita GDP in non-mining areas on the rural-urban income disparity before and after the policy year is $\operatorname{diff} f_{0}=\gamma_{4}$. This difference can be seen as a time trend difference in the impact of per capita GDP on the rural-urban income disparity excluding government policies. For the treatment areas in the treatment group (treated=1), the impact of per capita GDP of the regions on the rural-urban income disparity before and after the year of government policy is $\gamma_{1}+\gamma_{5}$ and $\gamma_{1}+\gamma_{4}+\gamma_{5}+\gamma_{7}$, and the difference is $\operatorname{diff}_{1}=\gamma_{4}+\gamma_{7}$. This difference includes not only the impact of the policy $\gamma_{7}$, but also the time trend differences $\gamma_{4}$. Therefore, the effect of policies on the rural-urban income disparity through economic growth is diff $=$ diff $f_{1}-$ diff $f_{0}=\gamma_{4}+\gamma_{7}-\gamma_{4}=\gamma_{7}$. This paper is concerned with the coefficient $\gamma_{7}$. If the policy increases the rural-urban income disparity through GDP growth, it should be significantly positive. The same with equation (1), the unobserved effect $v_{i}$ is eliminated through intra-group difference using panel data and get a consistent estimate. 
Table 1. variable definition

\begin{tabular}{|c|c|c|}
\hline variable & symbol & definition \\
\hline rural-urban income disparity & inc_ratio ${ }_{\text {it }}$ & $\begin{array}{l}\text { It's the ratio of annual per capita disposable income of urban households to annual } \\
\text { net income of rural households }\end{array}$ \\
\hline Economic growth rate & $\mathrm{GDP}_{\text {it }}$ & It's the ratio of annual regional GDP to total population \\
\hline investment rate & $\mathrm{RI}_{\mathrm{it}}$ & It's the ratio of annual fixed asset investment to regional GDP \\
\hline urbanization rate & $\mathrm{URB}_{\text {it }}$ & It's the ratio of the urban population to the total population \\
\hline social welfare undertakings & $\mathrm{PW}_{\text {it }}$ & the number of hospital beds in the area \\
\hline per capita education years & $\mathrm{ED}_{\text {it }}$ & $\begin{array}{l}\text { The calculation formula is: } \bar{Y}=\frac{\sum P_{i} E_{i}}{P} \text {, Where } \mathrm{P}_{\mathrm{i}} \text { is the number of the population } \\
\text { with the level of } \mathrm{i} \text { education, } \mathrm{E}_{\mathrm{i}} \text { is the education years of population with the level of } \\
\text { i education, } \mathrm{P} \text { is the total population. }\end{array}$ \\
\hline government intervention degree & $\mathrm{GI}_{\mathrm{it}}$ & Is equal to the ratio of local fiscal revenue to regional GDP \\
\hline
\end{tabular}

\section{Empirical Test and Analysis}

\subsection{Test the Mean Value of All Variables in the Experimental Group and the Control Group}

It can be seen from the table below that the result variables are significantly different between the two groups. The mean values of investment rate and government intervention were not significantly different between the two groups. Urbanization and education investment were significantly different between the two groups. We can do DID analysis.

Table 2. The mean values of all variables in the experimental group and the control group

\begin{tabular}{|c|c|c|c|c|}
\hline $\begin{array}{l}\text { Variable(s) } \\
\operatorname{Pr}(|T|>|t|)\end{array}$ & Mean Control & Mean Treated & Diff. & $|t|$ \\
\hline $\begin{array}{l}\text { inc_ratio } \\
0.0162 * *\end{array}$ & 2.071 & 2.385 & 0.313 & 3.04 \\
\hline $\begin{array}{l}\text { ri } \\
0.4084\end{array}$ & 27.812 & 34.552 & 6.740 & 0.87 \\
\hline $\begin{array}{l}\text { urb } \\
0.0053 * * *\end{array}$ & 32.692 & 44.500 & 11.808 & 3.79 \\
\hline $\begin{array}{l}\text { ed } \\
0.0176^{* *}\end{array}$ & 0.330 & 0.311 & -0.019 & 2.98 \\
\hline $\begin{array}{l}\text { gi } \\
0.5519\end{array}$ & 6.121 & 7.493 & 1.373 & 0.62 \\
\hline
\end{tabular}

\subsection{DID Test}

This paper uses fixed effect method and least square method (OLS) to estimate panel double difference model respectively. The time variation factors of variables are eliminated by first order difference. Since the policy dummy variables treated is time-invariant, it will be automatically omited when DID fixed-effect analysis is performed, but this does not affect the estimated results and its effectiveness. The panel DID test results of equation (1) are listed in table 3. Among them, models (1), (2), (3) and (4) are the OLS regression results, while models (5), (6), (7) and (8) are the regression results of fixed effects. Where columns (1) and columns (5) are estimated results without adding other control variables, column (2), (3), (4), (6), (7) and column (8) are the results of adding other control variables respectively. It can be seen that the coefficient of interaction term gd $(\mathrm{t} \times$ treated) is significantly positive whether other control variables are added or not. It shows that the development opinions on accelerating the development of key coal enterprises issued in 2003 have increased the rural-urban income disparity. Thus, formula (1) is proved. 
Table 3. DID test of the influence of policies on the rural-urban income disparity

\begin{tabular}{lcccccccc}
\hline variables & \multicolumn{3}{c}{ OLS } & \multicolumn{5}{c}{ fixed effect method } \\
& $(1)$ & $(2)$ & $(3)$ & $(4)$ & $(5)$ & $(6)$ & $(7)$ & $(8)$ \\
& inc_ratio & inc_ratio & inc_ratio & inc_ratio & inc_ratio & inc_ratio & inc_ratio & inc_ratio \\
\hline gd & $0.653^{* * *}$ & $0.675^{* * *}$ & $0.646^{* * *}$ & $0.633^{* * *}$ & $0.653^{* * *}$ & $0.675^{* * *}$ & $0.646^{* * * *}$ & $0.633^{* * * *}$ \\
& $(6.52)$ & $(4.33)$ & $(4.95)$ & $(4.61)$ & $(2.12 \mathrm{e}+15)$ & $(26.03)$ & $(6.55)$ & $(5.89)$ \\
$\mathrm{t}$ & $-0.214^{*}$ & -0.297 & -0.259 & -0.279 & -0.214 & -0.298 & -0.259 & -0.279 \\
& $(-2.34)$ & $(-1.61)$ & $(-1.42)$ & $(-1.49)$ & $(-1.32)$ & $(-1.16)$ & $(-0.75)$ & $(-0.79)$ \\
ri & & 0.0015 & 0.0014 & 0.0020 & & 0.0015 & 0.0015 & 0.0021 \\
& & $(0.53)$ & $(0.53)$ & $(0.71)$ & & $(0.87)$ & $(0.90)$ & $(1.12)$ \\
ed & & -0.476 & -0.476 & -0.526 & & & -0.476 & -0.526 \\
& & $(-0.69)$ & $(-0.69)$ & $(-0.78)$ & & & $(-0.38)$ & $(-0.42)$ \\
gi & & & & 0.0075 & & & & $0.00749^{* *}$ \\
& & & & $(0.42)$ & & & $(3.18)$ \\
cons & $2.228^{* * * *}$ & $2.180^{* * *}$ & $2.334^{* * *}$ & $2.281^{* * *}$ & $2.228^{* * *}$ & $2.180^{* * *}$ & $2.334^{* * *}$ & $2.281^{* * *}$ \\
& $(31.10)$ & $(18.98)$ & $(9.34)$ & $(7.69)$ & $(13.69)$ & $(20.61)$ & $(7.87)$ & $(7.81)$ \\
\hline$N$ & 28 & 28 & 28 & 28 & 28 & 28 & 28 & 28 \\
$R 2$ & 0.6282 & 0.6303 & 0.6415 & 0.6433 & 0.207 & 0.2045 & 0.2164 & 0.2164 \\
\hline
\end{tabular}

Note. the value in brackets is $\mathrm{t} / \mathrm{z}$ value. $*, * *$ and $* * *$ means respectively significant at $10 \%, 5 \%$ and $1 \%$ levels. Treated variables are omitted on regression due to time invariance.

In order to test the extent to which policies affect the rural-urban income disparity by promoting economic growth. The result is shown in column (1) of Table 4. Where column (1) is the estimated result without adding other control variables, it can be seen that the coefficient of lngdp is positive, indicating that economic growth has a positive impact on the increase of the rural-urban income disparity. The coefficient of the interaction term t_treated_lngdp $(\mathrm{t} \times$ treated $\times \operatorname{lngdp})$ was significantly positive, indicating that the policy aggravated the impact of economic growth on the rural-urban income disparity. Columns (2), (3), (4), and (5) are regression results that add other control variables respectively. It can be seen that the coefficient of the interaction term t_treated_lngdp $(\mathrm{t} \times$ treated $\times \operatorname{lngdp})$ is still significantly positive. This indicates that policies have increased the rural-urban income disparity by promoting economic growth. Thus, formula (2) is proved.

Table 4. OLS regression of policies effect on rural-urban income disparity by promoting GDP

\begin{tabular}{|c|c|c|c|c|c|}
\hline variables & $\begin{array}{c}\text { (1) } \\
\text { inc_ratio }\end{array}$ & $\begin{array}{c}\text { (2) } \\
\text { inc_ratio }\end{array}$ & $\begin{array}{c}\text { (3) } \\
\text { inc_ratio }\end{array}$ & $\begin{array}{c}\text { (4) } \\
\text { inc_ratio }\end{array}$ & $\begin{array}{c}\text { (5) } \\
\text { inc_ratio }\end{array}$ \\
\hline \multirow[t]{2}{*}{ lngdp } & $0.291^{\text {*** }}$ & $0.305^{* * *}$ & $0.287^{* * *}$ & $0.324^{* * * *}$ & 0.146 \\
\hline & $(5.90)$ & (14.52) & $(4.89)$ & (4.17) & $(0.41)$ \\
\hline \multirow[t]{2}{*}{$\mathrm{t}$} & $4.698^{* * *}$ & $4.814^{* * *}$ & $4.166^{* * * *}$ & $4.455^{* * *}$ & 2.861 \\
\hline & (10.76) & (22.24) & (57.14) & $(60.60)$ & (1.14) \\
\hline \multirow[t]{2}{*}{ t_lngdp } & $-0.507^{* * * *}$ & $-0.519^{* * * *}$ & $-0.450^{* * *}$ & $-0.478^{* * *}$ & -0.298 \\
\hline & $(-10.29)$ & $(-17.88)$ & $(-87.69)$ & $(-39.53)$ & $(-1.04)$ \\
\hline \multirow[t]{2}{*}{ treated_lngdp } & $0.0131^{* * *}$ & $0.0124^{* * *}$ & $0.0121^{*}$ & 0.0102 & 0.0250 \\
\hline & (3.89) & $(6.01)$ & $(2.17)$ & $(1.45)$ & $(0.80)$ \\
\hline \multirow[t]{2}{*}{$\mathrm{gd}$} & $-5.485^{* * *}$ & $-5.456^{* * *}$ & $-5.329^{* * *}$ & $-5.251^{* * *}$ & $-5.384^{* * * *}$ \\
\hline & $(-1.89 \mathrm{e}+12)$ & $(-69.27)$ & $(-28.66)$ & $(-28.56)$ & $(-12.25)$ \\
\hline \multirow[t]{2}{*}{ t_treated_lngdp } & $0.552^{* * *}$ & $0.550^{* * *}$ & $0.530^{* * *}$ & $0.523^{* * *}$ & $0.524^{* * *}$ \\
\hline & (163.43) & $(49.81)$ & $(24.22)$ & $(25.55)$ & (19.59) \\
\hline \multirow[t]{2}{*}{ ri } & & -0.000330 & & $-0.00085^{* * *}$ & $-0.00106^{*}$ \\
\hline & & $(-0.38)$ & & $(-7.82)$ & $(-2.09)$ \\
\hline \multirow[t]{2}{*}{ ed } & & & -0.633 & -0.641 & -0.551 \\
\hline & & & $(-0.84)$ & $(-0.82)$ & $(-0.53)$ \\
\hline \multirow[t]{2}{*}{ gi } & & & & & -0.0163 \\
\hline & & & & & $(-0.58)$ \\
\hline \multirow[t]{2}{*}{ _cons } & -0.505 & $-0.623^{* *}$ & -0.262 & -0.560 & 1.090 \\
\hline & $(-1.16)$ & $(-2.96)$ & $(-0.96)$ & $(-1.30)$ & $(0.36)$ \\
\hline$N$ & 28 & 28 & 28 & 28 & 28 \\
\hline$R 2$ & 0.7460 & 0.7462 & 0.7896 & 0.7906 & 0.8015 \\
\hline
\end{tabular}

Note. the value in brackets is $\mathrm{t} / \mathrm{z}$ value. $*, * *$ and $* * *$ means respectively significant at $10 \%, 5 \%$ and $1 \%$ levels. Treated variables are omitted on regression due to time invariance. 
The above results show that the effect of the policy on the rural-urban income disparity is as follows: 1) the policy increases the rural-urban income disparity. 2) the policy increases the effect of economic growth on the rural-urban income disparity.

\section{Robustness Tests}

This paper takes the starting point of issued the opinion of Inner Mongolia government on supporting the development of key coal enterprises in 2003, and the investigation period is from 1999 to 2012. In order to test the reliability of the empirical results in this paper, the study period of the treatment group and the control group was extended from 1999-2012 to 1987-2012. DID test was performed again for the above samples. Table 5 shows the OLS regression results of equation (1). Where model (1) is the estimated result without adding other control variables, columns (2), column (3), column (4) and column (5) are the results of adding other control variables respectively. It is not hard to see that the coefficient of interaction term $t \times$ treated is significantly positive whether other control variables are added or not. This shows that the policies introduced in 2003 have increased the rural-urban income disparity. Thus, formula (1) is verified, which is consistent with the basic regression results of this paper.

Table 5. The robust test of the policy's impact on rural-urban income disparity

\begin{tabular}{|c|c|c|c|c|c|}
\hline variables & $\begin{array}{c}\text { (1) } \\
\text { inc_ratio }\end{array}$ & $\begin{array}{c}\text { (2) } \\
\text { inc_ratio }\end{array}$ & $\begin{array}{c}\text { (3) } \\
\text { inc_ratio }\end{array}$ & $\begin{array}{c}(4) \\
\text { inc_ratio }\end{array}$ & $\begin{array}{c}\text { (5) } \\
\text { inc_ratio }\end{array}$ \\
\hline \multirow[t]{2}{*}{$\mathrm{gd}$} & $0.653^{* * * *}$ & $0.804^{* * *}$ & $0.710^{* * *}$ & $0.710^{* * *}$ & $0.627^{* * *}$ \\
\hline & $(6.75)$ & $(6.83)$ & $(5.17)$ & $(5.17)$ & $(4.78)$ \\
\hline \multirow[t]{2}{*}{$\mathrm{t}$} & $0.281^{* *}$ & $-0.281^{*}$ & $-0.232^{*}$ & $-0.232^{*}$ & $-0.394^{* *}$ \\
\hline & $(3.15)$ & $(-2.31)$ & $(-2.23)$ & $(-2.23)$ & $(-3.12)$ \\
\hline \multirow[t]{2}{*}{ ri } & & $0.0103^{* * *}$ & $0.00817^{* * *}$ & $0.00817^{* * *}$ & $0.0102^{* * *}$ \\
\hline & & (6.73) & (4.94) & (4.94) & $(5.60)$ \\
\hline \multirow[t]{2}{*}{ ed } & & & -1.077 & -1.077 & -0.990 \\
\hline & & & $(-1.41)$ & $(-1.41)$ & $(-1.33)$ \\
\hline \multirow[t]{2}{*}{ gi } & & & & & $0.0465^{* *}$ \\
\hline & & & & & $(3.01)$ \\
\hline \multirow[t]{2}{*}{ _cons } & $1.733^{* * *}$ & $1.416^{* * *}$ & $1.972^{* * *}$ & $1.972^{* * *}$ & $1.658^{* * * *}$ \\
\hline & $(24.64)$ & $(17.42)$ & $(5.45)$ & $(5.45)$ & $(4.71)$ \\
\hline$N$ & 70 & 70 & 70 & 70 & 70 \\
\hline$R 2$ & 0.3362 & 0.5420 & 0.5863 & 0.5863 & 0.6126 \\
\hline F value & 40.21 & 38.32 & 29.72 & 29.72 & 26.77 \\
\hline
\end{tabular}

Note. the value in brackets is $\mathrm{t}$ value. $*, * *$ and $* * *$ means respectively significant at $10 \%, 5 \%$ and $1 \%$ levels. Treated variables are omitted on regression due to time invariance.

In order to analyze the robustness of equation (2), the 1987-2012 data were used for further regression, and the results were shown in table 6 column (1). Where the column (1) is the estimated result without adding other control variables, it can be seen that the coefficient of lngdp is positive, indicating that economic growth has a positive impact on the increase of rural-urban income disparity. The coefficient of the interaction term t_treated_lngdp $(\mathrm{t} \times$ treated $\times \operatorname{lngdp})$ was significantly positive, indicating that the policy aggravated the impact of economic growth on the rural-urban income disparity. Columns (2), (3), (4) and (5) are regression results that add other control variables respectively. As we can see, the interaction term t_treated_lngdp ( $\times$ treated $\times \operatorname{lngdp})$ is still significantly positive. Thus, formula (2) is verified, which is consistent with the basic regression results of this paper.

Table 6. the robust test of the policy effect on the rural-urban income disparity through GDP

\begin{tabular}{lccccc}
\hline \multirow{2}{*}{ variables } & $(1)$ & $(2)$ & $(3)$ & $(4)$ & $(5)$ \\
& inc_ratio & inc_ratio & inc_ratio & inc_ratio & inc_ratio \\
\hline lngdp & 0.291 & $0.177^{* * *}$ & $0.210^{* * *}$ & $0.201^{* * *}$ & $0.190^{* * *}$ \\
& $(1.19)$ & $(3.56)$ & $(9.11)$ & $(7.42)$ & $(6.82)$ \\
$\mathrm{t}$ & 4.698 & $4.123^{* *}$ & $4.544^{* *}$ & $4.720^{* *}$ & $4.689^{* *}$ \\
& $(1.97)$ & $(3.22)$ & $(3.40)$ & $(2.87)$ & $(2.79)$ \\
\hline
\end{tabular}




\begin{tabular}{|c|c|c|c|c|c|}
\hline t_lngdp & $\begin{array}{l}-0.507 \\
(-1.92)\end{array}$ & $\begin{array}{c}-0.461^{* * *} \\
(-3.65)\end{array}$ & $\begin{array}{c}-0.456^{* * * *} \\
(-3.46)\end{array}$ & $\begin{array}{l}-0.522^{* *} \\
(-3.17)\end{array}$ & $\begin{array}{l}-0.522^{* *} \\
(-3.10)\end{array}$ \\
\hline treated_lngdp & $\begin{array}{c}0.0131 \\
(0.71)\end{array}$ & $\begin{array}{c}0.0175 \\
(1.26)\end{array}$ & $\begin{array}{c}0.0541^{* * *} \\
(3.91)\end{array}$ & $\begin{array}{c}0.0242^{*} \\
(2.10)\end{array}$ & $\begin{array}{c}0.0243^{*} \\
(2.12)\end{array}$ \\
\hline $\mathrm{gd}$ & $\begin{array}{c}-5.485^{* * *} \\
(-5.51)\end{array}$ & $\begin{array}{c}-6.150^{* * *} \\
(-4.91)\end{array}$ & $\begin{array}{c}-5.571^{* * *} \\
(-4.99)\end{array}$ & $\begin{array}{c}-6.262^{* * * *} \\
(-4.21)\end{array}$ & $\begin{array}{c}-6.187^{* * * *} \\
(-4.02)\end{array}$ \\
\hline t_treated_lngdp & $\begin{array}{c}0.552^{* * *} \\
(5.47)\end{array}$ & $\begin{array}{c}0.624^{\text {**** }} \\
(4.99)\end{array}$ & $\begin{array}{c}0.524^{* * *} \\
(4.66)\end{array}$ & $\begin{array}{c}0.633^{* * *} \\
(4.26)\end{array}$ & $\begin{array}{c}0.625^{* * * *} \\
(4.07)\end{array}$ \\
\hline ri & & $\begin{array}{c}0.00736^{* * * *} \\
(4.99)\end{array}$ & & $\begin{array}{c}0.00742^{* * *} \\
(4.84)\end{array}$ & $\begin{array}{c}0.00810^{\text {**** }} \\
(4.87)\end{array}$ \\
\hline ed & & & $\begin{array}{l}0.345 \\
(0.40)\end{array}$ & $\begin{array}{l}0.428 \\
(0.52)\end{array}$ & $\begin{array}{l}0.398 \\
(0.48)\end{array}$ \\
\hline gi & & & & & $\begin{array}{c}0.0161 \\
(1.01)\end{array}$ \\
\hline _cons & $\begin{array}{l}-0.505 \\
(-0.23) \\
\end{array}$ & $\begin{array}{l}0.119 \\
(0.29) \\
\end{array}$ & $\begin{array}{l}-0.192 \\
(-0.42) \\
\end{array}$ & $\begin{array}{l}-0.281 \\
(-0.59) \\
\end{array}$ & $\begin{array}{l}-0.276 \\
(-0.59) \\
\end{array}$ \\
\hline$N$ & 28 & 70 & 70 & 70 & 70 \\
\hline$R 2$ & 0.6448 & 0.7108 & 0.6468 & 0.7139 & 0.7166 \\
\hline$F$ value & 189.83 & 164.38 & 100.50 & 86.92 & 68.80 \\
\hline
\end{tabular}

Note. the value in brackets is t value. *,** and $* * *$ means respectively significant at $10 \%, 5 \%$ and $1 \%$ levels. Treated variables are omitted on regression due to time invariance.

The above results show that the effect of the policy on the rural-urban income disparity is as follows: 1) the policy increases the rural-urban income disparity. 2) the policy increases the effect of economic growth on the rural-urban income disparity. The empirical results are stable and reliable.

\section{Conclusions and Policy Implications}

The paper uses DID method of "quasi-natural experiment" to test whether the policy has promoted the economic growth of ordos while increasing the rural-urban income disparity. The results showed that the policy increased the rural-urban income disparity and increased the effect of economic growth on the rural-urban income disparity. In ordos, a city rich in natural resources, the economy has developed rapidly under the influence of policies. However, due to the single industry and the lack of good development of upstream and downstream enterprises, the urban economic development is difficult to drive the economic development of rural areas. During the rapid economic development of ordos, the rural-urban income disparity has also increased, and the increase rate is faster than that of neighboring cities. Therefore, in the process of economic development, the government needs to play a guiding role in reasonably transforming the benefits of mineral resources. We will increase the development of upstream and downstream industries of coal enterprises, improve rural infrastructure and public services, achieve urban-rural integration, reduce the income gap between urban and rural areas, then achieve sustainable economic development.

(1) In terms of mineral income distribution, due to the inadequate system of ecological environment compensation, the negative effect of ecological environment is very prominent in the process of mining coal resources. There is net loss of wealth in resource regions because of local governments do not have the financial resources to promote infrastructure, social development and ecological restoration (Jing puqiu et al., 2013). At the same time, some enterprises have not borne the social costs due to the lack of a regulatory mechanism for mineral income distribution. At this situation, vigorous development of mineral enterprises have high profits, resulting in a widening income gap between urban and rural areas. This vigorous development of resource enterprises attracts resources regional production factors, reduces the competitiveness of other relevant industrial sectors, and leads to the monotony of industry and the imbalance of industrial structure.

Therefore, a reasonable resource income distribution mechanism can be established to realize a reasonable distribution of resource benefits in resource-oriented regions such as ordos. Government should increase the disposable financial resources and invest the proceeds from resource in rural infrastructure and ecological and environmental development, so as to achieve urban-rural integration and reduce the income gap between urban and rural areas. At the same time, government should give greater support to the development of upstream and downstream industries of mining enterprises, achieve industrial clusters, absorb regional labor, increase employment, and reduce the rural-urban income disparity.

(2) In terms of the sustainable development of mineral enterprises, on the one hand, the development of mineral 
enterprises is affected by resource restrictions and policies due to their resource dependence. it is difficult to maximize the use of resources, resulting in the waste of a large number of resources that extensive mining of mineral resources and low comprehensive utilization of resources. At the same time, the mining of coal resources is accompanied by the waste of water resources. After the policy of 2003, the GDP growth and the coal resource production increased sharply, which realized the leapfrog economic growth. Meanwhile, after May 2012, due to the weak coal market, coal production in ordos has fallen.

Therefore, it is supposed to be establish a stable fund for coal enterprises for the stable development of mining enterprises. Charge a corresponding proportion of stable funds when the coal enterprises have surplus profits. When the coal market is weak, start a stabilization fund to give coal companies corresponding financial support. At the same time, to find a new way for coal resources, to achieve the transformation of coal resources. Transform coal resources into more convenient and clean energy sources, such as coal for oil, coal for electricity and coal for gas. At the same time, we will vigorously develop upstream and downstream coal enterprises, extend the industrial chain and increase the added value of products through science and technology, and cope with market fluctuations.

(3) In order to realize the integration of urban and rural development and reduce the rural-urban income disparity, it is necessary to invest the mineral resources income in material capital and human capital. Realizing the transformation of natural capital into other forms of capital, make up for the loss of mineral resources and other non-renewable resources. Appropriate investment in the income of coal resources in rural infrastructure construction, rural education and other areas. Invest capital in industries with externalities and projects that require larger initial capital or longer construction cycles such as education, health, transportation and energy.

\section{References}

Aghion, P., Eve, C., \& Garcia-Penalosa, C. (1999). Inequality and Economic Growth: The Perspective of the New Growth Theories. Journal of Economic Literature, 37(4), 1615-1660. http://dx.doi.org/10.1257/jel.37.4.1615

Alesina, A., \& Roberto, P. (1996). Income distribution, political instability, and investment. European Economic Review, 40(6), 1203-1228. https://doi.org/10.1016/0014-2921(95)00030-5

Binkai, C., \& Yifu, L. (2013). Development Strategy Urbanization and the Rural - urban Income Disparity in China. China Social Science, (4), 81-102.

Castello-Climent, A., \& Rafael, D. (2003). Human Capital Inequality, Life Expectancy and Economic Growth. The Economic Journal, 118(April), 643-677. https://doi.org/10.1111/j.1468-0297.2008.02136.x

Hua, X. (2011). The growth mechanism of "low price industrialization" is the fundamental cause of the imbalance of income distribution in China. Exploration of Economic Problems, (7), 107-112.

Kuznets, S. (1955). Economic growth and income inequality. American Economic Review, 45(1), 1-28. http://www.jstor.org/stable/1811581

Lewis, W. A. (1954). Economic Development with Unlimited Supplies of Labor. Manchester School, 22, 139-191. https://doi.org/10.1111/j.1467-9957.1954.tb00021.x

Puqiu, J., \& Hao, F. (2013). Mining revenue management and economic growth miracle: Botswana experience and enlightenment for China. Journal of China University of Geosciences, (2), 1-7.

Ravi, K., \& Xiaobo, Z. (2005). Fifty Years of Regional Inequality in China: A Journey Through Central Planning, Reform, and Openness. Review of Development Economics, 9(1), 87-106. https://doi.org/10.1111/j.1467-9361.2005.00265.x

Sherman, R. (1976). A Note on the U Hypothesis Relating Income Inequality and Economic Development. American Economic Review, 66(3), 437-40. Retrieved from http://www.jstor.org/stable/1828182

Stephen, K. (2005). Inequality and Economic Growth: The Empirical Relationship Reconsidered in the Light of Comparable Data. The Journal of Development Studies, 41(1), 135-159. https://doi.org/10.1080/0022038042000276590

Tongsan, W., \& Yuezhou, C. (2006). Impact of Income Distribution on Capital Accumulation and Investment Structure: An Empirical Study of China since the Reform and Opening-up. Chinese Social Science, (1), 4-14.

Wooldridge, J. M. (2007). Introduction to econometrics -- modern perspectives. Renmin university of China press. 
Xiaolu, W., \& Gang, F. (2005). Income Inequality in China and Its Influential Factors. Economic Research, (10), 24-36.

Yifu, L. (2012). Interpretation of China's economy. Peking University press.

\section{Notes}

Note 1. Guidance on accelerating the development of key coal enterprises in Inner Mongolia autonomous region, internal affairs [2003]427, December 15, 2003.

Note 2. Fan dianhua. (2012). Raising money in Ordos. Western Development, (8), 88-91.

Note 3. Lin yifu. (2012). Interpretation of China's economy (p. 217). Peking University press.

Note 4. http://www.mof.gov.cn/zhuantihuigu/neimenggu/meiti/200805/t20080519_26593.html.

\section{Copyrights}

Copyright for this article is retained by the author(s), with first publication rights granted to the journal.

This is an open-access article distributed under the terms and conditions of the Creative Commons Attribution license (http://creativecommons.org/licenses/by/4.0/). 